Terbit online pada laman web jurnal : http://jurnal.iaii.or.id

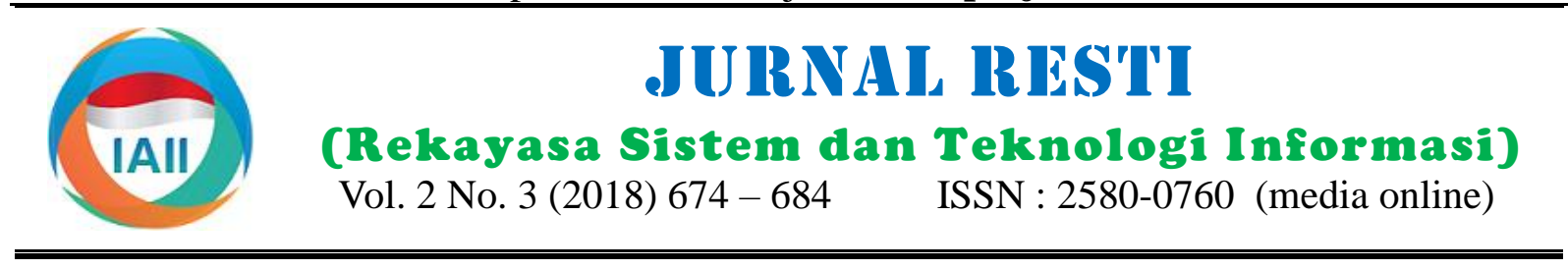

\title{
Prediksi Volume Penggunaan Air PDAM Menggunakan Metode Jaringan Syaraf Tiruan Backpropagation
}

\author{
Budy Satria \\ Teknik Komputer - AMIK Mitra Gama, budysatriadeveloper@gmail.com
}

\begin{abstract}
As the population growth rate in Duri increases, the need for clean water also increases as needed. In Indonesia, PDAM is an institution that regulates and manages the provision of clean water for the community. So the amount of water produced and distributed should be adjusted to the demand for water. However, the problem arises in the form of waste of water at PT. PDAM Duri. Purpose of this study is to predict the amount of water consumption at PT. PDAM Duri by implementing Backpropagation Artificial Neural Network method. Variables of data taken from customer data were social, general social, household 1, household 2, household 3, commerce 1, commerce 2 and commerce 3. Data used in the prediction process was training data in 2016 and data testing in 2017. Actual amount of data at PT. PDAM Duri City 2016 until 2017 was 2.840.165 when the prediction result using artificial neural network back propagation method was 2.843.388. The number of training epochs was 4595 and the achievement of MSE (Mean Squared Error) on the test was 0,001 and the result of accuracy was 99,99900000\%. Final result of this research was artificial neural network using back propagation method could predict the using of water consumption at PT. PDAM Duri for next year.
\end{abstract}

Keywords: Backpropagation, Artificial Intelligence, Prediction, PT. PDAM Duri , Neural Network Method.

\begin{abstract}
Abstrak
Seiring dengan meningkatnya laju pertumbuhan penduduk di kota Duri, kebutuhan akan air bersih pun meningkat sesuai kebutuhan. Di Indonesia, PDAM merupakan lembaga yang mengatur dan mengelola pengadaan air bersih bagi masyarakat. Jadi jumlah air yang diproduksi dan disalurkan sebaiknya disesuaikan dengan permintaan air. Namun, timbul persoalan berupa pemborosan air di PT. PDAM Kota Duri. Tujuan penelitian ini adalah melakukan prediksi jumlah penggunaan konsumsi air di PT. PDAM Kota Duri dengan menggunakan metode Jaringan Syaraf Tiruan Backpropagation. Variabel data diambil dari data pelanggan yaitu sosial umum, sosial khusus, rumah tangga 1 , rumah tangga 2 , rumah tangga 3 , niaga 1 , niaga 2 dan niaga 3. Data yang digunakan dalam proses prediksi adalah data pelatihan tahun 2016 dan data pengujian tahun 2017. Total data aktual pada PT. PDAM Kota Duri tahun 2016 s/d 2017 adalah 2.840 .165 sedangkan hasil perhitungan prediksi menggunakan Jaringan Syaraf Tiruan Metode Backpropagation adalah 2,843,388. Jumlah epoch pelatihan adalah 4595 dan pencapaian MSE (Mean Squared Error) pada pengujian adalah 0,001 serta hasil akurasi yang didapatkan adalah 99,99900000\%. Hasil akhir dari penelitian ini adalah jaringan syaraf tiruan menggunakan metode backpropagation dapat memprediksi penggunaan konsumsi air di PT. PDAM Kota Duri untuk tahun selanjutnya.
\end{abstract}

Kata kunci: Propagasi Balik, Kecerdasan Buatan, Prediksi, PT. PDAM Duri, Metode Jaringan Syaraf Tiruan.

(C) 2018 Jurnal RESTI

\section{Pendahuluan}

Air sebagai salah satu kebutuhan utama untuk menunjang kehidupan manusia dan merupakan salah satu sumber daya alam yang memiliki fungsi sangat penting serta merupakan komponen lingkungan hidup yang bermanfaat bagi kelangsungan hidup manusia dan makhluk hidup lainnya. Seiring dengan meningkatnya laju pertumbuhan penduduk di kota Duri, kebutuhan akan air bersih pun meningkat sesuai kebutuhan. Di Indonesia, PDAM merupakan lembaga yang mengatur dan mengelola pengadaan air bersih bagi masyarakat. kecerdasan buatan dengan metode Jaringan Syaraf Jadi jumlah air yang diproduksi dan disalurkan Tiruan (JST). Konsep dari JST untuk memprediksi Diterima Redaksi : 24-09-2018 | Selesai Revisi : 12-10-2018 | Diterbitkan Online : 15-12-2018 sebaiknya disesuaikan dengan permintaan air. Namun, timbul persoalan berupa pemborosan air di PT. PDAM Kota Duri. Ada permasalahan dalam menghadapi kebutuhan air, salah satunya apabila jumlah air yang di produksi dan disalurkan lebih besar daripada permintaan akan air, maka timbul persoalan pemborosan volume air pada PDAM. Dalam hal ini diperlukan sebuah prediksi untuk mengetahui kebutuhan manajemen produksi jumlah air PDAM. 
jumlah produksi air PDAM dengan cara mengolah data jumlah produksi air PDAM periode masa lalu yang dimasukkan kedalam sistem dilakukan proses pelatihan menggunakan JST dengan metode Backpropagation. Setelah dilakukan proses pelatihan, sistem akan menghasilkan bobot-bobot yang akan digunakan untuk memprediksi jumlah produksi air 3. PDAM pada periode tahun-tahun selanjutnya. Kecerdasan buatan (Artificial Inteligence) merupakan cabang ilmu komputer yang konsern dengan pengautomatisan tingkah laku [1].

Jaringan syaraf tiruan telah banyak digunakan dalam berbagai permasalahan diantaranya pada penelitian sebelumnya tentang platform jaringan syaraf tiruan feedforward digital yang menggunakan algoritma backpropagation selama pelatihan untuk memungkinkan putaran energi [2]. Jaringan syaraf tiruan juga bisa digunakan untuk peramalan beban listrik [3]. Jaringan syaraf tiruan digunakan untuk peramalan kunjungan rawat jalan menggunakan dekomposisi mode empiris ditambah dengan jaringan syaraf tiruan backpropagation [4]. Jaringan syaraf tiruan juga digunakan untuk prediksi deret waktu muncul di banyak masalah dunia nyata, misalnya, pasar keuangan, pemrosesan sinyal, peramalan cuaca antara lain [5] dan juga untuk peramalan yang mengintegrasikan transformasi wavelet diskrit dan jaringan saraf backpropagation untuk memprediksi deret waktu keuangan [6].

\section{Tinjauan Pustaka}

\subsection{Kecerdasan Buatan}

Kecerdasan buatan atau (Artificial Intelligence) merupakan bidang ilmu komputer yang membuat agar $b$ komputer dapat melakukan pekerjaan seperti dan sebaik yang dilakukan oleh manusia [7]. Teknologi kecerdasan buatan dipelajari dalam beberapa bidang, seperti : Robotika dan Sistem Sensor, Penglihatan Komputer (Computer Vision), Sistem Saraf Tiruan (Artificial Neural System), Agen Cerdas (Intelligent Agent), Pengenalan Suara (Speech Recognition), Permainan (Game Playing) dan Sistem Pakar (Expert System). [8]

\subsection{Definisi Jaringan Syaraf Tiruan}

Jaringan syaraf tiruan merupakan salah satu metode berbasis kecerdasan buatan, yang mampu mengidentifikasi pola, signal prosesing serta peramalan dari sistem dengan metode pembelajaran [9]. Dalam jaringan syaraf tiruan terdapat konsep yakni setiap pola-pola informasi input dan output yang diberikan ke dalam JST diproses dalam neuron. Neuron-neuron tersebut terkumpul di dalam lapisanlapisan yang disebut neuron layers [10]. Lapisanlapisan penyusun JST tersebut dapat dibagi menjadi 3, yaitu :
1. Lapisan Input, unit-unit di dalam lapisan input disebut unit-unit input. Unit-unit input tersebut menerima pola inputan data dari luar yang menggambarkan suatu permasalahan.

2. Lapisan tersembunyi, unit - unit didalam lapisan tersembunyi disebut unit -unit tersembunyi.

3. Lapisan output, unit - unit didalam lapisan output disebut unit - unit output.

\subsection{Definisi Prediksi}

Dalam penelitian ini dibutuhkan beberapa teori yang berhubungan dengan prediksi diantaranya adalah : Prediksi (forecasting) adalah suatu kegiatan yang memperkirakan apa yang terjadi pada masa akan datang. Masalah pengambilan keputusan merupakan masalah yang dihadapi maka peramalan juga merupakan masalah yang harus dihadapi, karena peramalan berkaitan erat dengan pengambilan suatu keputusan [11].

\subsection{Backpropagation}

Backpropagation merupakan algoritma pembelajaran yang terawasi dan biasanya digunakan oleh perceptron dengan banyak lapisan untuk mengubah bobot-bobot yang terhubung dengan neuron-neuron yang ada pada lapisan tersembunyinya[12]. Secara garis besar, training jaringan dengan dengan metode backpropagation meliputi tiga tahap [13]:

a. Tahap maju (feedforward)

Tahap feedforward yang dimaksud adalah proses pengolahan input dari pola input training pada input layer sampai respon yang dihasilkan mencapai output layer

b. Tahap perhitungan error propagasi balik (backpropagation of error)

Respon yang dihasilkan pada output layer akan dibandingkan dengan output target, kemudian dihitung errornya. Bila kriteria untuk kondisi berhenti (stopping condition) belum terpenuhi, maka dilanjutkan ke tahap ketiga (adjustment of the weights and biases). Namun jika kondisi berhenti sudah terpenuhi, maka proses perhitungan berhenti.

c. Tahap pembaharuan bobot dan bias (adjustment of the weights and biases)

Kondisi ini terjadi jika output yang diharapkan tidak sesuai, maka jaringan akan bergerak mundur (backward) dari output layer menuju ke input layer dan akan melakukan update bobot dan bisa serta mengulangi proses dari tahap 1. Backpropagation merupakan algoritma pembelajaran yang biasanya digunakan oleh perceptron dengan banyak lapisan untuk mengubah bobot-bobot yang terhubung dengan neuron-neuron yang ada pada lapisan tersembunyinya [14]. 
Algoritma pembelajaran untuk JST Backpropagation adalah sebagai berikut :

Langkah 0 : Inisialisasi bobot dengan nilai random atau acak yang cukup kecil.

Langkah 1 : Selama kondisi berhenti belum terpenuhi, Memperbaharui nilai bobot dan nilai bias: laksanakan langkah sampai 9.

Langkah 2 : Untuk tiap pasang pelatihan, kerjakan langkah 3 sampai 8

Langkah 3 : Untuk tiap input neuron (Xi,i=1,2,3,..,n) menerima input xi dan menyebarkan sinyal tersebut ke seluruh neuron kepada lapisan atasnya (lapisan tersembunyi).

Langkah 4 : Untuk hidden neuron ( $\mathrm{Zi}, \mathrm{j}=1,2,3, \ldots, \mathrm{p})$ dihitung nilai input dengan menggunakan nilai bobotnya:

$$
z_{-} i n_{j}=V_{o j}+\sum_{i=1}^{n} X_{i} V_{i j}
$$

Kemudian dihitung nilai output dengan menggunakan fungsi aktivasi yang digunakan:

$$
\mathrm{zj}=\mathrm{f}\left(\mathrm{z} \_ \text {in } \mathrm{j}\right)
$$

Di mana fungsi aktivasi yang digunakan adalah fungsi sigmoid biner yang mempunyai persamaan:

$$
f(x)=\frac{1}{1+\delta^{x}}
$$

Langkah 5 : Untuk tiap output neuron (Yk, $\mathrm{k}=1,2,3, \ldots, \mathrm{m})$ dihitung nilai input dengan nilai bobotnya

$$
\sum_{i=1}^{p} Z_{i} W_{j k}
$$

Kemudian dihitung nilai output dengan menggunakan fungsi aktivasi: $y k=f\left(y \_\right.$ink $)$

Langkah 6 : Untuk tiap output neuron (Yk, $\mathrm{k}=1,2,3, \ldots, \mathrm{m})$ menerima pola target yang bersesuaian dengan pola input dan kemudian dihitung informasi kesalahan: $\quad \Delta \mathrm{k}=(\mathrm{tk}-\mathrm{yk}) \mathrm{f}^{\prime}\left(\mathrm{y} \_\right.$ink $)$

Kemudian dihitung koreksi nilai bobot yang kemudian akan digunakan untuk memperbaharui nilai $\Delta$ wjk : wjk $=\alpha \delta \mathrm{kzj}$

Hitung koreksi nilai bias yang kemudian akan digunakan untuk memperbaharui nilai $\mathrm{w} 0 \mathrm{k}: \Delta \mathrm{w} 0 \mathrm{k}=\alpha$ $\delta \mathrm{k}$ Dan kemudian nilai $\delta \mathrm{k}$ dikirim ke neuron pada lapisan sebelumnya.

Langkah 7 : Untuk tiap hidden neuron $(\mathrm{Zj}$, $j=1,2,3, \ldots, p)$

$$
\delta_{-} i n_{j}=\sum_{k=1}^{m} \delta_{k} W_{j k}
$$

Kemudian nilai tersebut dikalikan dengan nilai turunan dari fungsi aktivasi untuk menghitung informasi kesalahan: $\delta \mathrm{j}=\delta$ in $\mathrm{j} \quad \mathrm{f}^{\prime}\left(\mathrm{z} \_\right.$inj $)$

Hitung koreksi nilai bobot yang kemudian digunakan untuk memperbaharui vij :

$$
\Delta v i j=\alpha \delta \mathrm{j} \mathrm{xi}
$$

Dan hitung nilai koreksi bias yang kemudian digunakan untuk memperbaharui nilai

$$
\mathrm{v} 0 \mathrm{j}: \Delta v 0 \mathrm{j}=\alpha \delta \mathrm{j}
$$

Langkah 8 : Tiap nilai bias dan bobot $(j=0, \ldots, p)$ pada output neuron $(\mathrm{Yk}, \mathrm{k}=1,2,3, \ldots, \mathrm{m})$ diperbaharui: wjk (baru) $=w j k($ lama $)+\Delta v$ ij

Vij (baru) $=\operatorname{vij}($ lama $)+\Delta v$ ij

\section{Metodologi Penelitian}

Penelitian ini dilakukan di PT. PDAM Kota Duri, pengumpulan data dan informasi digunakan pendekatan deskriptif atau survey yaitu mengumpulkan data dari data pelanggan yaitu sosial umum, sosial khusus, rumah tangga 1, rumah tangga 2 , rumah tangga 3 , niaga 1, niaga 2 dan niaga 3 dari tahun 2016-2017. Data tersebut kemudian dianalisis dan digunakan sebagai data pelatihan (training) dan data pengujian (testing). Algoritma Jaringan Syaraf Tiruan Backpropagation untuk memprediksi volume penggunaan air di PT. PDAM Kota Duri adalah sebagai berikut :

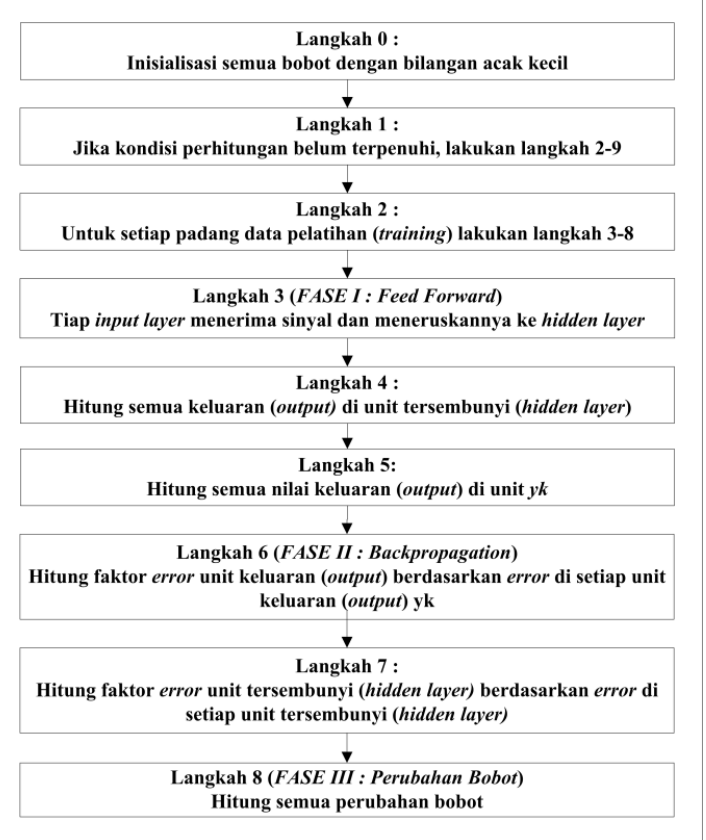

Gambar 1: Alur Backpropagatio

\section{Hasil dan Pembahasan}

\subsection{Analisa Data}

Pada tahapan ini, data yang telah diperoleh dari PT. PDAM Kota Duri akan dibagi menjadi 2 kelompok yaitu data pelatihan (training) dan data pengujian (testing) pada Jaringan Syaraf Tiruan (JST). Data yang dibutuhkan adalah data dari PT. PDAM Kota Duri dari tahun 2016 (pelatihan) dan 2017 (pengujian) 
Budy Satria

Jurnal RESTI (Rekayasa Sistem dan Teknologi Informasi) Vol. 2 No. 3 (2018) $674-684$

Tabel 1. Data Penggunaan Air di PT. PDAM Kota Duri Tahun 2016/2017

Pelanggan Air Bersih PT. PDAM Kota Duri

\begin{tabular}{|c|c|c|c|c|c|c|c|c|c|c|}
\hline Tahun & Bulan & $\begin{array}{c}\text { Sosial } \\
\text { Umum } \\
\mathrm{M}^{3}\end{array}$ & $\begin{array}{c}\text { Sosial } \\
\text { Khusus } \\
\mathrm{M}^{3}\end{array}$ & $\begin{array}{c}\text { Rumah } \\
\text { Tangga } 1 \\
\mathrm{M}^{3}\end{array}$ & $\begin{array}{c}\text { Rumah } \\
\text { Tangga } 2 \\
\mathrm{M}^{3}\end{array}$ & $\begin{array}{c}\text { Rumah } \\
\text { Tangga } 3 \\
\mathrm{M}^{3}\end{array}$ & $\begin{array}{c}\text { Niaga } 1 \\
\mathrm{M}^{3}\end{array}$ & $\begin{array}{c}\text { Niaga } 2 \\
\mathrm{M}^{3}\end{array}$ & $\begin{array}{c}\text { Niaga } 3 \\
\mathrm{M}^{3}\end{array}$ & $\begin{array}{c}\text { Jumlah } \\
\text { Air } \\
\mathrm{M}^{3}\end{array}$ \\
\hline \multirow{12}{*}{2016} & Jan & 4.044 & 1.001 & 19.244 & 103.347 & 2.640 & 2.293 & 10.169 & 644 & 143.382 \\
\hline & Feb & 3.175 & 982 & 17.855 & 90.029 & 2.298 & 1.895 & 8.941 & 532 & 125.707 \\
\hline & Mar & 2.418 & 835 & 14.742 & 76.744 & 2.219 & 1.629 & 7.580 & 474 & 106.641 \\
\hline & Apr & 3.361 & 1.023 & 19.653 & 106.867 & 2.890 & 2.278 & 9.775 & 459 & 146.306 \\
\hline & Mei & 3.449 & 916 & 1.823 & 95.898 & 2.484 & 1.827 & 8.931 & 428 & 132.163 \\
\hline & Jun & 3.277 & 669 & 16.158 & 84.361 & 2.041 & 1.600 & 8.544 & 1.156 & 117.806 \\
\hline & Jul & 2.949 & 666 & 17.309 & 91.295 & 2.271 & 1.767 & 9.233 & 1.318 & 126.808 \\
\hline & Aug & 2.641 & 1.068 & 17.937 & 93.900 & 2.219 & 1.909 & 9.539 & 1.177 & 130.390 \\
\hline & Sept & 2.403 & 865 & 1.527 & 79.447 & 2.012 & 1.499 & 7.993 & 712 & 110.201 \\
\hline & Okt & 2.865 & 1.017 & 17.581 & 91.133 & 2.213 & 1.665 & 8.615 & 1.205 & 126.294 \\
\hline & Nov & 2.777 & 1.043 & 17.138 & 91.159 & 2.410 & 1.665 & 9.063 & 103 & 126.285 \\
\hline & Des & 2.100 & 1.892 & 12.807 & 64.796 & 1.645 & 1.269 & 6.343 & 882 & 91.734 \\
\hline \multirow{12}{*}{2017} & Jan & 2.380 & 2.856 & 18.487 & 94.359 & 2.252 & 1.933 & 10.450 & 710 & 133.427 \\
\hline & Feb & 2.852 & 2.285 & 16.243 & 70.837 & 2.321 & 1.669 & 8.980 & 731 & 105.918 \\
\hline & Mar & 2.710 & 2.716 & 14.789 & 77.271 & 1.734 & 1.737 & 9.345 & 656 & 110.958 \\
\hline & Apr & 2.836 & 4.140 & 16.848 & 88.322 & 3.837 & 1.698 & 8.866 & 708 & 127.255 \\
\hline & Mei & 2.859 & 3.021 & 17.023 & 88.001 & 5.444 & 2.275 & 8.693 & 1.322 & 128.638 \\
\hline & Jun & 2.699 & 3.146 & 12.099 & 66.856 & 4.504 & 1.975 & 6.038 & 1.218 & 98.535 \\
\hline & Jul & 2.907 & 3.950 & 13.564 & 81.069 & 5.410 & 2.133 & 7.524 & 527 & 117.084 \\
\hline & Aug & 3.071 & 4.095 & 13.247 & 81.779 & 6.571 & 2.538 & 7.427 & 370 & 119.098 \\
\hline & Sept & 3.072 & 4.049 & 11.267 & 83.687 & 7.694 & 3.159 & 8.036 & 296 & 121.260 \\
\hline & Okt & 2.418 & 3.191 & 7.560 & 64.950 & 7.681 & 2.890 & 6.874 & 266 & 95.830 \\
\hline & Nov & 2.182 & 1.280 & 7.146 & 69.607 & 9.248 & 2.945 & 6.210 & 391 & 99.009 \\
\hline & Des & 2.287 & 1.197 & 6.484 & 68.749 & 9.677 & 3.326 & 7.232 & 484 & 99.436 \\
\hline
\end{tabular}

Sumber: PT. PDAM Kota Duri Tahun 2016 s/d 2017

Berikut merupakan variabel- variabel yang akan ditransformasikan ke interval yang lebih kecil, digunakan dalam memprediksi jumlah penggunaan air misalnya pada interval $[0.1,0.8]$ adalah: bersih di PT. PDAM Kota Duri:

1. Sosial Umum

2. Sosial Khusus

3. Rumah Tangga 1

4. Rumah Tangga 2

5. Rumah Tangga 3

6. Niaga 1

7. Niaga 2

8. Niaga 3

9. Jumlah Penggunaan air (ditetapkan sebagai data Target).

Fungsi aktivasi yang digunakan untuk mengolah data pelatihan (training) dan pengujian (testing) di atas adalah fungsi sigmoid (biner), maka data harus ditransformasikan terlebih dahulu karena range (batas) keluaran fungsi aktivasi sigmoid adalah fungsi asimtotik (tidak pernah mencapai 0 ataupun 1). Data

$$
X=\frac{0,8(x-a)}{b-a}+0,1
$$

Berikut merupakan variabel- variabel yang akan digunakan dalam memprediksi jumlah penggunaan air bersih di PT. PDAM Kota Duri:
1. Sosial Umum
2. Sosial Khusus
3. Rumah Tangga 1
4. Rumah Tangga 2
5. Rumah Tangga 3
6. Niaga 1
7. Niaga 2
8. Niaga 3
9. Jumlah Penggunaan air (ditetapkan sebagai data Target). 
Fungsi aktivasi yang digunakan untuk mengolah data pelatihan (training) dan pengujian (testing) di atas adalah fungsi sigmoid (biner), maka data harus ditransformasikan terlebih dahulu karena range (batas) keluaran fungsi aktivasi sigmoid adalah fungsi asimtotik (tidak pernah mencapai 0 ataupun 1). Data ditransformasikan ke interval yang lebih kecil, misalnya pada interval $[0.1,0.8]$ adalah:

$X=\frac{0,8(x-a)}{b-a}+0,1$

Keterangan :

$0.8=$ Ketetapan

$\mathrm{X}=$ Nilai data $\mathrm{ke}-\mathrm{n}$

A = Nilai data terendah (data terendah dari setiap input)

$\mathrm{B}=$ Nilai data tertinggi (data tertinggi dari setiap input)

Berikut merupakan data variabel dan inisialisasi data Tabel 3 adalah hasil transformasi dari data pelatihan transformasi data dengan mengambil sampel data pada (training) tahun 2016 dan data pengujian (testing) bulan januari pada setiap variabel :

Tabel 2. Pendataan Variabel dan Inisialisasi Data

\begin{tabular}{|c|c|c|c|}
\hline No & Variabel & Inisialisasi & Nilai \\
\hline \multirow{2}{*}{1} & Sosial & \multirow{2}{*}{$\mathrm{X} 1$} & $A=2100$ \\
\hline & Umum & & $B=4044$ \\
\hline \multirow{2}{*}{2} & Sosial & \multirow{2}{*}{$\mathrm{X} 2$} & $A=666$ \\
\hline & Khusus & & $B=4140$ \\
\hline \multirow{2}{*}{3} & Rumah & \multirow{2}{*}{$\mathrm{X} 3$} & $A=6484$ \\
\hline & Tangga 1 & & $B=19653$ \\
\hline \multirow{2}{*}{4} & Rumah & \multirow{2}{*}{$\mathrm{X} 4$} & $A=64796$ \\
\hline & Tangga 2 & & $B=106867$ \\
\hline \multirow{2}{*}{5} & Rumah & \multirow{2}{*}{ X5 } & $A=1645$ \\
\hline & Tangga 3 & & $B=9677$ \\
\hline \multirow{2}{*}{6} & \multirow{2}{*}{ Niaga 1} & \multirow{2}{*}{ X6 } & $A=1269$ \\
\hline & & & $B=3326$ \\
\hline \multirow{2}{*}{7} & \multirow{2}{*}{ Niaga 2} & \multirow{2}{*}{$\mathrm{X} 7$} & $A=6038$ \\
\hline & & & $B=10450$ \\
\hline \multirow{2}{*}{8} & \multirow{2}{*}{ Niaga 3} & \multirow{2}{*}{$\mathrm{X} 8$} & $A=266$ \\
\hline & & & $B=1322$ \\
\hline \multirow{2}{*}{9} & \multirow{2}{*}{ Target } & \multirow{2}{*}{$\mathrm{T}$} & $A=91734$ \\
\hline & & & $B=146306$ \\
\hline
\end{tabular}

Berikut merupakan sampel cara perhitungan transformasi data :

1. Variabel pada Sosial Umum (X1)

$\mathrm{X} 1=(0,8 *(4044-2100) /(4044-2100))+$ $0,1=0,9000$

2. Variabel pada Sosial Khusus (X2) $\mathrm{X} 1=(0,8 *(1001-666) /(4140-666))+0,1$ $=0,1771$

3. Variabel Rumah Tangga 1 (X3)
$\mathrm{X} 2=(0,8 *(19244-6484) /(19653-6484))+$ $0,1=0,8752$

4. Variabel Rumah Tangga 2 (X4) $\mathrm{X} 3=(0,8 *(103347-64796) /(106867$ 64796)) $+0,1=0,8331$

5. Variabel Rumah Tangga 3 (X5) $\mathrm{X} 4=0,8 *(2640-1645) /(9677-1645))+0,1$ $=0,1991$

6. Variabel Niaga 1 (X6) $\mathrm{X} 5=(0,8 *(2293-1269) /(3326-1269))+$ $0,1=0,4982$

7. Variabel Niaga $2(X 7)$ $\mathrm{X} 5=(0,8 *(10169-6038) /(10450-6038))+$ $0,1=0,8490$

8. Variabel Niaga $3(\mathrm{X} 8)$ $\mathrm{X} 5=(0,8 *(644-266) /(1322-266)+0,1$ $=0,3864$

9. Variabel Penggunaan Air (Target) $\mathrm{T}=(0,8 *(143382-91734) /(146306$ $91734))+0,1=0,8571$ tahun 2017 yang nantinya digunakan sebagai data untuk pengolahan menggunakan algoritma backpropagation serta tabel nilai bobot dengan inisial ( $V$ ) dari input layer (lapisan masukan) ke hidden layer (lapisan tersembunyi) didapat dari hasil pengolahan di aplikasi Matlab R2011.

Langkah - langkah Perhitungan sebagai berikut :

Langkah 0 : Inisialisasi semua bobot dengan bilangan acak kecil.

Langkah 1 : Jika kondisi perhitungan belum terpenuhi, lakukan langkah 2-9.

Langkah 2 : Untuk setiap pasang data pelatihan, lakukan 3-8.

Fase I : Propagasi Maju (feed forward)

Langkah 3 : Tiap input layer menerima sinyal dan meneruskannya ke hidden layer diatasnya.

Langkah 4 : Hitung semua keluaran (output) di unit tersembunyi (hidden layer) $\mathrm{Zj}(\mathrm{j}=1,2 \ldots, \mathrm{p})$

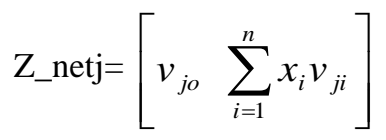

Z_net $1=-9,0218+(0,9000 * 4.0893)+(0,1771 *$ $-12.6059)+(0,8572 * 3.8926)+(0,8331 * 2.6772)+$ $(0,1991 *-5.1347)+(0,4982 *-5.8459)+(0,8490 *$

Z_net $2=3,1878+(0,9000 * 3.8117)+(0,1771 *$ $(0,1991 *-7.1776)+(0,4982 * 3.3908)+(0,8490 *$ $-2.6528)+(0,3864 *-2.7386)=-5,2182$

Z_net $3=-9.6652+(0,9000 *-4.1231)+(0,1771 *$ $14.3192)+(0,8572 *-7.4235)+(0,8331 *-2.4658)+$ $(0,1991 * 18.9344)+(0,4982 * 3.4449)+(0,8490 *$ $0.0759)+(0,3864 * 4.1219)=0,7459$
$3.7648)+(0,3864 * 5.2527)=-0,6467$ $12.5258)+(0,8572 *-8.3892)+(0,8331 *-4.3976)+$ 
Budy Satria

Jurnal RESTI (Rekayasa Sistem dan Teknologi Informasi) Vol. 2 No. 3 (2018) 674 - 684

Tabel 3. Data Hasil Transformasi Pola Pelatihan (training) dan Pengujian (testing) Tahun 2016/2017

\begin{tabular}{|c|c|c|c|c|c|c|c|c|c|c|}
\hline \multicolumn{11}{|c|}{ Pelanggan Air Bersih PT. PDAM Kota Duri } \\
\hline Tahun & Bulan & $\mathrm{X} 1$ & $\mathrm{X} 2$ & $\mathrm{X} 3$ & $\mathrm{X} 4$ & $\mathrm{X} 5$ & $\mathrm{X} 6$ & $\mathrm{X} 7$ & $\mathrm{X} 8$ & $\mathrm{~T}$ \\
\hline \multirow{11}{*}{2016} & Jan & 0.9000 & 0.1771 & 0.8752 & 0.8331 & 0.1991 & 0.4982 & 0.8490 & 0.3864 & 0.8571 \\
\hline & Feb & 0.5424 & 0.1728 & 0.7908 & 0.5798 & 0.1650 & 0.3435 & 0.6264 & 0.3015 & 0.5980 \\
\hline & Mar & 0.2309 & 0.1389 & 0.6017 & 0.3272 & 0.1572 & 0.2400 & 0.3796 & 0.2576 & 0.3185 \\
\hline & Apr & 0.6189 & 0.1822 & 0.9000 & 0.9000 & 0.2240 & 0.4924 & 0.7776 & 0.2462 & 0.9000 \\
\hline & Mei & 0.6551 & 0.1576 & 0.8136 & 0.6914 & 0.1836 & 0.3170 & 0.6246 & 0.2227 & 0.6927 \\
\hline & Jun & 0.5844 & 0.1007 & 0.6877 & 0.4720 & 0.1394 & 0.2287 & 0.5544 & 0.7742 & 0.4822 \\
\hline & Jul & 0.4494 & 0.1000 & 0.7576 & 0.6039 & 0.1624 & 0.2937 & 0.6793 & 0.8970 & 0.6142 \\
\hline & Aug & 0.3226 & 0.1926 & 0.7958 & 0.6534 & 0.1572 & 0.3489 & 0.7348 & 0.7902 & 0.6667 \\
\hline & Sept & 0.2247 & 0.1458 & 0.6337 & 0.3786 & 0.1366 & 0.1895 & 0.4545 & 0.4379 & 0.3707 \\
\hline & Okt & 0.4148 & 0.1808 & 0.7741 & 0.6008 & 0.1566 & 0.2540 & 0.5673 & 0.8114 & 0.6066 \\
\hline & Nov & 0.3786 & 0.1868 & 0.7472 & 0.6013 & 0.1762 & 0.2540 & 0.6485 & 0.6788 & 0.6065 \\
\hline \multirow{13}{*}{2017} & Des & 0.1000 & 0.3823 & 0.4841 & 0.1000 & 0.1000 & 0.1000 & 0.1553 & 0.5667 & 0.1000 \\
\hline & Jan & 0.2152 & 0.6043 & 0.8292 & 0.6622 & 0.1605 & 0.3582 & 0.9000 & 0.4364 & 0.7112 \\
\hline & Feb & 0.4095 & 0.4728 & 0.6928 & 0.2149 & 0.1673 & 0.2556 & 0.6335 & 0.4523 & 0.3079 \\
\hline & Mar & 0.3510 & 0.5721 & 0.6045 & 0.3372 & 0.1089 & 0.2820 & 0.6996 & 0.3955 & 0.3818 \\
\hline & Apr & 0.4029 & 0.9000 & 0.7296 & 0.5474 & 0.3183 & 0.2668 & 0.6128 & 0.4348 & 0.6207 \\
\hline & Mei & 0.4123 & 0.6423 & 0.7402 & 0.5413 & 0.4784 & 0.4912 & 0.5814 & 0.9000 & 0.6410 \\
\hline & Jun & 0.3465 & 0.6711 & 0.4411 & 0.1392 & 0.3848 & 0.3746 & 0.1000 & 0.8212 & 0.1997 \\
\hline & Jul & 0.4321 & 0.8562 & 0.5301 & 0.4094 & 0.4750 & 0.4360 & 0.3694 & 0.2977 & 0.4716 \\
\hline & Aug & 0.4996 & 0.8896 & 0.5108 & 0.4229 & 0.5906 & 0.5935 & 0.3519 & 0.1788 & 0.5011 \\
\hline & Sept & 0.5000 & 0.8790 & 0.3906 & 0.4592 & 0.7025 & 0.8351 & 0.4623 & 0.1227 & 0.5328 \\
\hline & Okt & 0.2309 & 0.6815 & 0.1654 & 0.1029 & 0.7012 & 0.7304 & 0.2516 & 0.1000 & 0.1600 \\
\hline & Nov & 0.1337 & 0.2414 & 0.1402 & 0.1915 & 0.8573 & 0.7518 & 0.1312 & 0.1947 & 0.2066 \\
\hline & Des & 0.1770 & 0.2223 & 0.1000 & 0.1752 & 0.9000 & 0.9000 & 0.3165 & 0.2652 & 0.2129 \\
\hline
\end{tabular}

Tabel 4. Nilai Bobot Awal Input Layer ke Hidden Layer dari Matlab R2011

\begin{tabular}{cccccccccc}
\hline Bobot & Z1 & Z2 & Z3 & Z4 & Z5 & Z6 & Z7 & Z8 & Z9 \\
\hline V1 & 4.0893 & 3.8117 & -4.1231 & 4.1327 & 1.3154 & -4.5069 & -3.0457 & 0.6456 & 5.0714 \\
V2 & -12.6059 & 12.5258 & 14.3192 & -0.4143 & 8.4562 & -11.3636 & -3.0484 & 16.2216 & 9.1783 \\
V3 & 3.8926 & -8.3892 & 7.4235 & 8.3462 & 3.4169 & 5.5521 & 6.4309 & -2.8547 & 3.3153 \\
V4 & 2.6772 & -4.3976 & -2.4658 & -4.5372 & -4.0038 & 3.6222 & 2.6789 & -2.5186 & 4.9907 \\
V5 & -5.1347 & -7.1776 & 18.9344 & 19.0398 & -20.0764 & -0.7395 & -4.8270 & 12.9980 & 14.9724 \\
V6 & -5.8459 & 3.3908 & 3.4439 & -6.7757 & -7.6063 & -0.0368 & 12.6988 & -4.4151 & 1.8987 \\
V7 & 3.7648 & -2.6528 & 0.0759 & 2.2951 & 4.4799 & 5.9311 & 0.7487 & -5.7383 & -4.4830 \\
V8 & 5.2527 & -2.7386 & 4.1219 & -3.0424 & 5.0618 & -1.9933 & -4.9500 & -4.0669 & 1.5263 \\
\hline
\end{tabular}

Tabel 5. Nilai Bobot Hidden Layer ke Output Layer dari Matlab R2011

\begin{tabular}{cc}
\hline Bobot & $\mathrm{Y}$ \\
\hline W1 & $-0,2967$ \\
W2 & 0,6617 \\
W3 & 0,1705 \\
W4 & 0,0994 \\
W5 & 0,8344 \\
W6 & $-0,4283$ \\
W7 & 0,5144 \\
W8 & 0,5075 \\
W9 & $-0,2391$ \\
\hline
\end{tabular}

Tabel 6. Nilai Bias Input Layer ke Hidden Layer dari Matlab R2011

\begin{tabular}{cc}
\hline Bobot & $\mathrm{Vj}$ \\
\hline $\mathrm{W} 1$ & $-9,0218$ \\
$\mathrm{~W} 2$ & 3,1878 \\
$\mathrm{~W} 3$ & $-9,6652$ \\
$\mathrm{~W} 4$ & $-7,2256$ \\
W5 & $-3,0306$ \\
W6 & $-2,8061$ \\
W7 & 5,3978 \\
W8 & 5,4479 \\
W9 & $-8,2315$ \\
\hline
\end{tabular}

Jurnal RESTI (Rekayasa Sistem dan Teknologi Informasi) Vol . 2 No. 3 (2018) 674 - 684 
Tabel 7. Nilai Bias Hidden Layer ke Output Layer dari Matlab $R 2011$

\begin{tabular}{cc}
\hline Bias & $\mathrm{Y}$ \\
\hline $\mathrm{Wj}$ & $-0,8483$
\end{tabular}

Z_net $4=-7.2256+(0,9000 * 4.1327)+(0,1771 *$ $-0.4143)+(0,8572 * 8.3462)+(0,8331 *-4.5372)+$ $(0,1991 * 19.0398)+(0,4982 *-6.7757)+(0,8490 *$ $2.2951+(0,3864 *-3.0424)=1,1329$

Z_net $5=-3,0306+(0,9000 * 1.3154)+(0,1771 *$ $8.4562)+(0,8572 * 3.4169)+(0,8331 *-4.0038+$ $(0,1991 *-20.0764)+(0,4982 *-7.6063)+(0,8490 *$ $4.4799)+(0,3864 * 5.0618)=-2,7217$

Z_net $6=-2,8061+(0,9000 *-4.5069)+(0,1771 *$ $-11.3636)+(0,8572 * 5.5521)+(0,83313.6222)+$ $(0,1991 *-0.7395)+(0,4982 *-0.0368)+(0,8490 *$ $-5.9311+(0,3864 *-1.9933)=3,1012$

Z_net $7=-5,3978+(0,9000 *-3.0457)+(0,1771 *$ $-3.0484)+(0,8572 * 6.4309)+(0,8331 * 2.6789)+$ $(0,1991 *-4.8270)+(0,4982 * 12.6988)+(0,8490 *$ $0.7487)+(0,3864 *-4.9500)=3,2701$

Z_net $8=5.4476+(0,9000 * 0.6456)+(0,1771 *$ $16.2216)+(0,8572 *-2.8547)+(0,8331 *-2.5186)+$ $(0,1991 * 12.9980)+(0,4982 *-4.4151)+(0,8490 *$ $-5.7383)+(0,3864 *-4.0669)=-1,7492$

Z_net $9=-8.2315+(0,9000 * 5.0714)+(0,1771 *$ $9.1783)+(0,8572 * 3.3153)+(0,8331 * 4.9907)+$ $(0,1991 * 14.9724)+(0,4982 * 1.8987)+(0,8490 *$ $-4.4830)+(0,3864 * 1.5263)=5,7281$

Kemudian mencari nilai sigmoid :

$\mathrm{Z}_{1}=$ sigmoid $[-0,6467]=\frac{1}{1+e^{-(-0,6467)}}=0,3437$

$\mathrm{Z}_{2}=\operatorname{sigmoid}[-5,2182]=\frac{1}{1+e^{-(-5,2182)}}=0,0054$

$\mathrm{Z} 3=$ sigmoid $[0,7459]=\frac{1}{1+e^{-(0,7459)}}=0,6783$

$\mathrm{Z} 4=$ sigmoid $[1,1329]=\frac{1}{1+e^{-(1,1329)}}=0,7564$

$\mathrm{Z} 5=$ sigmoid $[-2,7217]=\frac{1}{1+e^{-(-2,7217)}}=0,0617$

$\mathrm{Z} 6=$ sigmoid $[3,1012]=\frac{1}{1+e^{-(3,1012)}}=0,9569$

$\mathrm{Z} 7=\operatorname{sigmoid}[3,2701]=\frac{1}{1+e^{-(3,2701)}}=0,9634$

$\mathrm{Z} 8=$ sigmoid $[-1,7492]=\frac{1}{1+e^{-(-1,7492)}}=0,1481$

$\mathrm{Z} 9=$ sigmoid $[5,7281]=\frac{1}{1+e^{-(5,7281)}}=0,9968$

Langkah 5 : Hitung semua nilai keluaran di unit yk (k $=1,2, . ., \mathrm{m})$
Karena jaringannya hanya memiliki sebuah unit keluaran y maka y_net k

y_netk =

Y_net $\mathrm{k}=-0,8483+(0,3437 * 0,2967)+(0,0054 *$ $0,6617)+(0,6783 * 0,1705)+(0,7564 * 0,0994)+$ $(0,0617 * 0,8344)+(0,9569 *-0,4283)+(0,9634 *$ $0,5144)+(0,1481 * 0,5075)+\left(0,9968^{*}-0,2391\right)+$ $(0,6848 * 0,1356)=-0,6889$

(sesuai dengan nilai Y di Aplikasi Matlab R2011b) $=$ sigmoid $[-0,6899]$

$=1 /\left(1+\mathrm{e}^{\wedge}(-(-0,6899))\right)$

$=0,3343$

Fase 2 : Propagasi Mundur (backpropagation)

Langkah ke 6 : Hitung faktor berdasarkan kesalahan setiap unit keluaran $\mathrm{Yk}$

$$
\begin{aligned}
\delta_{\mathrm{k}} & =(\mathrm{tk}-\mathrm{yk}) \mathrm{yk}\left(1 \_\mathrm{yk}\right) \\
& =(0,8571-0,3343) 0,3343 *(1-0,3343) \\
& =0,1164
\end{aligned}
$$

Hitung perubahan bobot $W_{J k}$ (digunakan dalam mengubah bobot $W_{J k}$ ) dengan laju pembelajaran (learning rate) $\alpha=0,5$ dengan persamaan:

$\Delta w_{[1,1]}=\alpha * \delta_{k} * z_{1}$ $=0,5 *(0,1164) * 0,3437=0,0200$

$\Delta w_{[1,2]}=\alpha \delta_{k} z_{2}$

$=0,5 *(0,1164) * 0,0054=0,0003$

$\Delta w_{[1,3]}=\alpha \delta_{k} z_{3}$ $=0,5 *(0,1164) * 0,6783=0,0395$

$\Delta w_{[1,4]}=\alpha \delta_{k} z_{4}$ $=0,5 *(0,1164) * 0,7564=0,0440$

$\Delta w_{[1,5]}=\alpha \delta_{k} z_{5}$ $=0,5 *(0,1164) * 0,0617=0,0036$

$\Delta w_{[1,6]}=\alpha \delta_{k} z_{6}$ $=0,5 *(0,1164) * 0,9569=0,0096$

$\Delta w_{[1,7]}=\alpha \delta_{k} z_{7}$ $=0,5 *(0,1164) * 0,9634=0,0002$

$\Delta w_{[1,8]}=\alpha \delta_{k} z_{8}$ $=0,5 *(0,1164) * 0,1481=0,0029$

$\Delta w_{[1,9]}=\alpha \delta_{k} z_{9}$ $=0,5 *(0,1164) * 0,9968=0,0219$

$\Delta w_{[0]}=\alpha * \delta$ $=0,5 *(0,1164)=0,0582$

Langkah 7 : Hitung faktor error $\delta$ unit tersembunyi (hidden layer) berdasarkan error di setiap unit tersembunyi (hidden layer) $\mathrm{z}_{-} \mathrm{j}(\mathrm{j}=1,2, \ldots, \mathrm{p})$.

$$
\begin{aligned}
& \delta_{\text {net }(j)}=\sum_{k=1}^{m}\left(\delta_{k} \cdot w_{k j}\right) \\
& \delta_{\text {inj }}=\delta_{k} \cdot w_{j k} \\
& \delta_{\text {net } 1}=(0,1164) * 0,2967=0,0345 \\
& \delta_{\text {net } 2}=(0,1164) * 0,6617=0,0770 \\
& \delta_{\text {net } 3}=(0,1164) * 0,1705=0,0198 \\
& \delta_{\text {net } 4}=(0,1164) * 0,0994=0,0116
\end{aligned}
$$




$$
\begin{aligned}
& \delta_{\text {net } 5}=(0,1164) * 0,8344=-0,0971 \\
& \delta_{\text {net } 6}=(0,1164) *-0,4283=-0,0498 \\
& \delta_{\text {net } 7}=(0,1164) * 0,5144=0,0599 \\
& \delta_{\text {net } 8}=(0,1164) * 0,5075=0,0591 \\
& \delta_{\text {net } 9}=(0,1164) *-0,2391=-0,0278
\end{aligned}
$$

Kemudian hitung faktor error $\delta$ di unit tersembunyi (hidden layer) dengan rumus persamaan:

$$
\begin{aligned}
& \delta_{k}=\delta_{\text {net } j} f^{\prime}\left(z_{-} n e t_{j}\right)=\delta_{\text {net } j} * Z_{j} *\left(1-z_{j}\right) \\
& \delta_{1}=(0,0345) * 0,3437 *(1-0,3439)=-0,0078 \\
& \delta_{2}=(0,0770) * 0,0054 *(1-0,0054)=0,0004 \\
& \delta_{3}=(0,0198) * 0,6783 *(1-0,6784)=0,0043 \\
& \delta_{4}=(0,0116) * 0,7564 *(1-0,7564)=0,0021 \\
& \delta_{5}=(-0,0971) * 0,0617 *(1-0,0617)=0,0056 \\
& \delta_{6}=(-0,0498) * 0,9569 *(1-0,9569)=-0,0021 \\
& \delta_{7}=(0,0599) * 0,9634 *(1-0,9634)=0,0021 \\
& \delta_{8}=(0,0591) * 0,1481 *(1-0,1481)=0,0075 \\
& \delta_{9}=(-0,0278) * 0,9968 *(1-0,9968)=-0,0001
\end{aligned}
$$

Hitung suku perubahan bobot (baru) ke unit tersembunyi (hidden layer) dengan rumus persamaan:

$$
\Delta v_{0 . j}=\alpha * \delta_{j} * x_{i} \text { dimana } \alpha=0,5
$$

$$
\begin{aligned}
& X 1=0,9000 \\
& \Delta v_{1.1}=0,5 *(-0,0078) * 0,9000=-0,0035 \\
& \Delta v_{1.2}=0,5 *(0,0004) * 0,9000=0,0002 \\
& \Delta v_{1.3}=0,5 *(0,0043) * 0,9000=0,0019 \\
& \Delta v_{1.4}=0,5 *(0,0021) * 0,9000=0,0010 \\
& \Delta v_{1.5}=0,5 *(0,0056) * 0,9000=0,0025 \\
& \Delta v_{1.6}=0,5 *(-0,0021) * 0,9000=-0,0009 \\
& \Delta v_{1.7}=0,5 *(0,0021) * 0,9000=0,0010 \\
& \Delta v_{1.8}=0,5 *(0,0075) * 0,9000=0,0034 \\
& \Delta v_{1.9}=0,5 *(-0,0001) * 0,9000=-0,0000 \\
& \Delta v_{1.10}=0,5 *(0,0034) * 0,9000=0,0015
\end{aligned}
$$

$$
\begin{gathered}
X 2=0,1771 \\
\Delta v_{2.1}=0,5 *(0,0078) * 0,1771=-0,0007 \\
\Delta v_{2.2}=0,5 *(0,0004) * 0,1771=0,0000 \\
\Delta v_{2.3}=0,5 *(0,0043) * 0,1771=0,0004 \\
\Delta v_{2.4}=0,5 *(0,0021) * 0,1771=0,0002 \\
\Delta v_{2.5}=0,5 *(0,0056) * 0,1771=0,0005 \\
\Delta v_{2.6}=0,5 *(-0,0021) * 0,1771=-0,0002 \\
\Delta v_{2.7}=0,5 *(0,0021) * 0,1771=0,0002 \\
\Delta v_{2.8}=0,5 *(0,0075) * 0,1771=0,0007 \\
\Delta v_{2.9}=0,5 *(-0,0001) * 0,1771=0,0000 \\
\Delta v_{2.10}=0,5 *(0,0034) * 0,1771=0,0003
\end{gathered}
$$

\section{$X 3=0,8752$}

$$
\begin{aligned}
& \Delta v_{3.1}=0,5 *(0,0078) * 0,8752=-0,0034 \\
& \Delta v_{3.2}=0,5 *(0,0004) * 0,8752=0,0002 \\
& \Delta v_{3.3}=0,5 *(0,0043) * 0,8752=0,0019 \\
& \Delta v_{3.4}=0,5 *(0,0021) * 0,8752=0,0009 \\
& \Delta v_{3.5}=0,5 *(0,0056) * 0,8752=0,0025 \\
& \Delta v_{3.6}=0,5 *(-0,0021) * 0,8752=-0,0009 \\
& \Delta v_{3.7}=0,5 *(0,0021) * 0,8752=0,0009
\end{aligned}
$$

$$
\begin{aligned}
& \Delta v_{3.8}=0,5 *(0,0075) * 0,8752=0,0033 \\
& \Delta v_{3.9}=0,5 *(-0,0001) * 0,8752=0,0000 \\
& \Delta v_{3.10}=0,5 *(0,0034) * 0,8752=0,0015
\end{aligned}
$$

$X 4=0,8331$

$$
\begin{aligned}
& \Delta v_{4.1}=0,5 *(0,0078) * 0,8331=-0,0032 \\
& \Delta v_{4.2}=0,5 *(0,0004) * 0,8331=0,0002 \\
& \Delta v_{4.3}=0,5 *(0,0042) * 0,8331=0,0018 \\
& \Delta v_{4.4}=0,5 *(0,0021) * 0,8331=0,0009 \\
& \Delta v_{4.5}=0,5 *(0,0054) * 0,8331=0,0023 \\
& \Delta v_{4.6}=0,5 *(-0,0021) * 0,8331=-0,0009 \\
& \Delta v_{4.7}=0,5 *(0,0021) * 0,8331=0,0009 \\
& \Delta v_{4.8}=0,5 *(0,0075) * 0,8331=0,0031 \\
& \Delta v_{4.9}=0,5 *(-0,0001) * 0,8331=0,0000 \\
& \Delta v_{4.10}=0,5 *(0,0034) * 0,8331=0,0014
\end{aligned}
$$

$X 5=0,1991$

$$
\begin{aligned}
& \Delta v_{5.1}=0,5 *(0,0078) * 0,1991=-0,0008 \\
& \Delta v_{5.2}=0,5 *(0,0004) * 0,1991=0,0000 \\
& \Delta v_{5.3}=0,5 *(0,0043) * 0,1991=0,0004 \\
& \Delta v_{5.4}=0,5 *(0,0021) * 0,1991=0,0002 \\
& \Delta v_{5.5}=0,5 *(0,0056) * 0,1991=0,0006 \\
& \Delta v_{5.6}=0,5 *(-0,0021) * 0,1991=-0,0002 \\
& \Delta v_{5.7}=0,5 *(0,0020) * 0,1991=0,0002 \\
& \Delta v_{5.8}=0,5 *(0,0075) * 0,1991=0,0007 \\
& \Delta v_{5.9}=0,5 *(-0,0001) * 0,1991=0,0000 \\
& \Delta v_{5.10}=0,5 *(0,0034) * 0,1991=0,0003
\end{aligned}
$$

$$
\begin{aligned}
X 6=0,4982 & \\
\Delta v_{6.1}=0,5 *(0,0078) * 0,4982 & =-0,0019 \\
\Delta v_{6.2}=0,5 *(0,0004) * 0,4982 & =0,0001 \\
\Delta v_{6.3}=0,5 *(0,0043) * 0,4982 & =0,0011 \\
\Delta v_{6.4}=0,5 *(0,0021) * 0,4982 & =0,0005 \\
\Delta v_{6.5}=0,5 *(0,0054) * 0,4982 & =0,0014 \\
\Delta v_{6.6}=0,5 *(-0,0021) * 0,4982 & =-0,0005 \\
\Delta v_{6.7}=0,5 *(0,0021) * 0,4982 & =0,0005 \\
\Delta v_{6.8}=0,5 *(0,0075) * 0,4982 & =0,0019 \\
\Delta v_{6.9}=0,5 *(-0,0001) * 0,4982 & =0,0000 \\
\Delta v_{6.10}=0,5 *(0,0034) * 0,4982 & =0,0008
\end{aligned}
$$

$$
\begin{array}{cl}
X 7=0,8490 & \\
\Delta v_{7.1}=0,5 *(0,0078) * 0,8490 & =-0,0033 \\
\Delta v_{7.2}=0,5 *(0,0004) * 0,8490 & =0,0002 \\
\Delta v_{7.3}=0,5 *(0,0043) * 0,8490 & =0,0018 \\
\Delta v_{7.4}=0,5 *(0,0021) * 0,8490 & =0,0009 \\
\Delta v_{7.5}=0,5 *(0,0056) * 0,8490 & =0,0024 \\
\Delta v_{7.6}=0,5 *(-0,0021) * 0,8490 & =-0,0009 \\
\Delta v_{7.7}=0,5 *(0,0021) * 0,8490 & =0,0009 \\
\Delta v_{7.8}=0,5 *(0,0075) * 0,8490 & =0,0032 \\
\Delta v_{7.9}=0,5 *(-0,0001) * 0,8490 & =0,0000 \\
\Delta v_{7.10}=0,5 *(0,0034) * 0,8490 & =0,0014 \\
& \\
X 8=0,3864 & \\
\Delta v_{8.1}=0,5 *(0,0078) * 0,3864 & =-0,0015 \\
\Delta v_{8.2}=0,5 *(0,0004) * 0,3864 & =0,0001 \\
\Delta v_{8.3}=0,5 *(0,0043) * 0,3864 & =0,0008 \\
\Delta v_{8.4}=0,5 *(0,0021) * 0,3864 & =0,0004
\end{array}
$$


Budy Satria

Jurnal RESTI (Rekayasa Sistem dan Teknologi Informasi) Vol . 2 No. 3 (2018) 674 - 684

$$
\begin{aligned}
& \Delta v_{8.5}=0,5 *(0,0056) * 0,3864=0,0011 \\
& \Delta v_{8.6}=0,5 *(-0,0021) * 0,3864=-0,0004 \\
& \Delta v_{8.7}=0,5 *(0,0021) * 0,3864=0,0004 \\
& \Delta v_{8.8}=0,5 *(0,0075) * 0,3864=0,0014 \\
& \Delta v_{8.9}=0,5 *(-0,0001) * 0,3864=0,0000 \\
& \Delta v_{8.10}=0,5 *(0,0034) * 0,3864=0,0007
\end{aligned}
$$

Langkah selanjutnya hitung koreksi nilai Bias dari unit tersembunyi (hidden layer).

$$
\Delta V_{j o}=\alpha * \delta_{j}
$$

$\Delta \mathrm{V}_{j 1}=0,5 *(0,0078)=-0,0039$

$\Delta \mathrm{V}_{j 2}=0,5 *(0,0004)=0,0002$

$\Delta \mathrm{V}_{j 3}=0,5 *(-0,0043)=0,0022$

$\Delta \mathrm{V}_{j 4}=0,5 *(0,0021)=0,0011$

$\Delta \mathrm{V}_{j 5}=0,5 *(0,0056)=0,0028$

$\Delta \mathrm{V}_{j 6}=0,5 *(-0,0021)=-0,0011$

$\Delta \mathrm{V}_{j 7}=0,5 *(0,0021)=0,0011$

$\Delta \mathrm{V}_{j 8}=0,5 *(0,0075)=0,0037$

$\Delta \mathrm{V}_{j 9}=0,5 *(-0,0001)=0,0000$

\section{Fase III : Perubahan Bobot}

Langkah 8 : Hitung semua perubahan bobot.

Langkah setelah ini adalah menghitung nilai bobot unit tersembunyi (hidden) dengan persamaan:

$$
\begin{aligned}
& V_{o j}(\text { baru })=V_{o j}(\text { lama })+\Delta V_{o j} \\
& V_{1.1(\text { baru })}=V_{1.1(\text { lama })}+\Delta \mathrm{v}_{1.1} \\
& =4,0893+(-0,0035)=4,0858 \\
& V_{1.2(\text { baru })}=V_{1.2(\text { lama })}+\Delta \mathrm{v}_{1.2} \\
& =-12,6059+(0,0007)=-12,6066 \\
& V_{1.3 \text { (baru })}=V_{1.3(\text { lama })}+\Delta \mathrm{v}_{1.3} \\
& =3,8926+(0,0034)=3,8892 \\
& V_{1.4(\text { baru })}=V_{1.4(\text { lama })}+\Delta \mathrm{v}_{1.4} \\
& =2,6772+(0,0032)=2,6740 \\
& V_{1.5(\text { baru })}=V_{1.5(\text { lama })}+\Delta \mathrm{v}_{1.5} \\
& =-5,1347+(0,0008)=-5,1355 \\
& V_{1.6(\text { baru })}=V_{1.6(\text { lama })}+\Delta \mathrm{v}_{1.6} \\
& =-5,8449+(-0,0019)=-5,8478 \\
& V_{1.7 \text { (baru })}=V_{1,7 \text { lama })}+\Delta \mathrm{v}_{1.7} \\
& =3,7648+(0,0033)=3,7615 \\
& V_{1.8(\text { baru })}=V_{1,8(\text { lama })}+\Delta \mathrm{v}_{1.8} \\
& =5,2527+(0,0015)=5,2512
\end{aligned}
$$

hitung perubahan nilai bobot garis yang menuju ke unit keluaran (output) dengan rumus persamaan :

$$
\begin{aligned}
& \quad W_{o j}(\text { baru })=W_{o j}(\text { lama })+\Delta W_{o j} \\
& W_{1(\text { baru })}=w_{1(\text { lama })}+\Delta w_{1} \\
& =(-0,2967)+(0,0200)=0,2767 \\
& W_{2(\text { baru })}=w_{2(\text { lama })}+\Delta w_{2} \\
& =(0,6617)+(0,0003)=0,6620 \\
& W_{3(\text { baru })}=w_{3(\text { lama })}+\Delta w_{3}
\end{aligned}
$$

$$
\begin{aligned}
& =(0,1705)+(0,0395)=0,2100 \\
& W_{4(\text { baru })}=w_{4(\text { lama })}+\Delta w_{4} \\
& =(0,0994)+(0,0440)=0,1434 \\
& W_{5(\text { baru })}=w_{5(\text { lama })}+\Delta w_{5} \\
& =(0,8344)+(0,0036)=0,8380 \\
& W_{6(\text { baru })}=w_{6(\text { lama })}+\Delta w_{6} \\
& =(-0,4283)+(0,0096)=-0,4187 \\
& W_{7(\text { baru })}=w_{7(\text { lama })}+\Delta w_{7} \\
& =(0,5144)+(0,0002)=0,5146 \\
& W_{8(\text { baru })}=w_{8(\text { lama })}+\Delta w_{8} \\
& =(0,5075)+(0,0029)=0,5104 \\
& W_{9(\text { baru })}=w_{9(\text { lama })}+\Delta w_{9} \\
& =(-0,2391)+(0,0219)=-0,2172
\end{aligned}
$$

Kemudian hitung perubahan nilai bias dari unit tersembunyi (hidden layer) ke output:

$W_{j 0(\text { bias baru })}=w_{0(\text { lama })}+\Delta w_{0}$
$=-0,8483+0,0582=-0,7901$

Setelah proses pelatihan selesai, data keluaran (output) yang sudah didapatkan dari pelatihan jaringan yang masih dalam bentuk normalisasi, sehingga mesti dilakukannya proses denormalisasi data yang bertujuan untuk mengembalikan nilai hasil keluaran data yang masih dalam bentuk normalisasi ke dalam bentuk data yang sebenarnya, dengan persamaan :

$$
\begin{aligned}
X^{\prime} & =x\left(x_{\max }-x_{\min }\right)+x_{\min } \\
X^{\prime} & =-0,6889(146306-91734)+91734 \\
& =54135,60132
\end{aligned}
$$

Hasil denormalisasi dari keluaran target $-0,6889$ yang dihasilkan adalah 54135,60132. Hasil ini dinilai masih mengandung nilai error yang besar, karena target yang harus dicapai adalah 2840,165 (Target).

\subsection{Implementasi Pada Matlab R2011b}

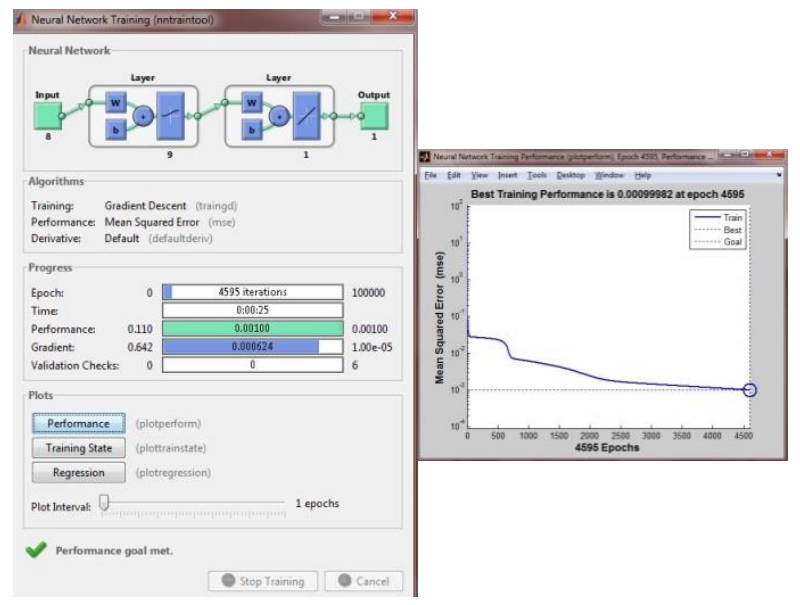

Gambar 2 : Pola dan Grafik Goal Pelatihan 8-9-1

Jurnal RESTI (Rekayasa Sistem dan Teknologi Informasi) Vol . 2 No. 3 (2018) 674 - 684 


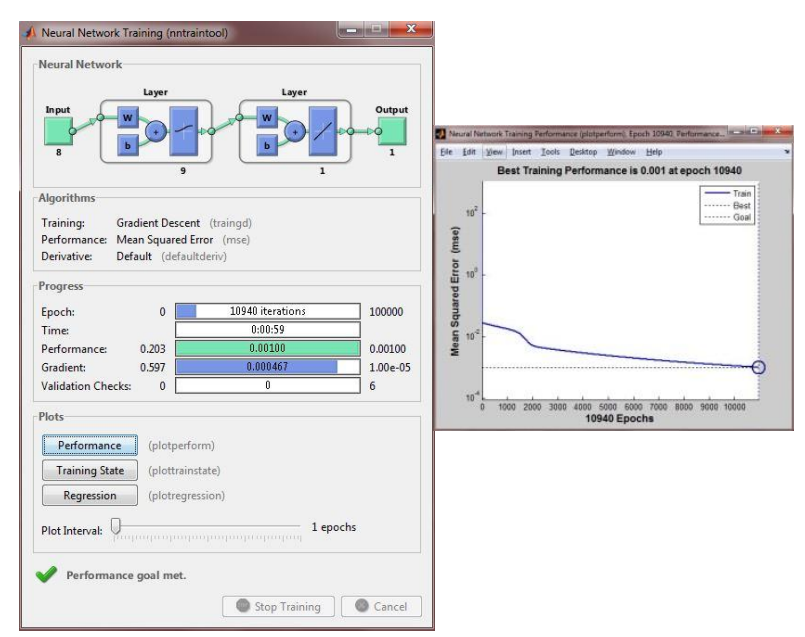

Gambar 3 : Goal Pengujian Data dengan Pola 8-9-1

\begin{tabular}{ccccc}
\multicolumn{4}{c}{ Tabel 8. Perbandingan Terhadap Pola Pengujian } \\
\hline No & Pola & $\begin{array}{c}\text { Epoch } \\
\text { (Pelatihan) }\end{array}$ & $\begin{array}{c}\text { MSE } \\
\text { (Pengujian) }\end{array}$ & $\begin{array}{c}\text { Akurasi (100- } \\
\text { MSE) }\end{array}$ \\
\hline 1 & $8-7-1$ & 1845 & 0,00099986 & $99,99900014 \%$ \\
2 & $8-8-1$ & 7850 & 0,00099987 & $99,99900014 \%$ \\
$\mathbf{3}$ & $\mathbf{8 - 9 - 1}$ & $\mathbf{4 5 9 5}$ & $\mathbf{0 , 0 0 1}$ & $\mathbf{9 9 , 9 9 9 0 0 0 0 0 \%}$ \\
4 & $8-10-1$ & 6517 & 0,00099982 & $99,99900018 \%$ \\
\hline
\end{tabular}

\begin{tabular}{|c|c|c|c|}
\hline Tahun & Bulan & Data Aktual & Data JST \\
\hline \multirow{11}{*}{2016} & Jan & 143382 & 138409 \\
\hline & Feb & 125707 & 124052 \\
\hline & Mar & 106641 & 110278 \\
\hline & Apr & 146306 & 139403 \\
\hline & Mei & 132163 & 129923 \\
\hline & Jun & 117806 & 116919 \\
\hline & Jul & 126808 & 124390 \\
\hline & Aug & 130390 & 125039 \\
\hline & Sept & 110201 & 111942 \\
\hline & Okt & 126294 & 129236 \\
\hline & Nov & 126285 & 125923 \\
\hline \multirow{15}{*}{2017} & Des & 91734 & 97088 \\
\hline & Jan & 133427 & 127964 \\
\hline & Feb & 105918 & 107691 \\
\hline & Mar & 110958 & 115085 \\
\hline & Apr & 127255 & 125667 \\
\hline & Mei & 128638 & 127413 \\
\hline & Jun & 98535 & 102015 \\
\hline & Jul & 117084 & 120073 \\
\hline & Aug & 119098 & 117159 \\
\hline & Sept & 121260 & 120892 \\
\hline & Okt & 95830 & 103129 \\
\hline & Nov & 99009 & 101830 \\
\hline & Des & 99436 & 101868 \\
\hline & Total & 2.840 .165 & 2.843.388 \\
\hline & Rata -Rata & 118.340 & 118.475 \\
\hline
\end{tabular}

Dapat dilihat jumlah data aktual adalah 2.840.165 hampir mendekati dengan hasil prediksi menggunakan pola 8-9-1 dengan hasil perhitungan yaitu 2.843.388.

Dari Tabel dan gambar yang ada dapat dilihat perbandingan data prediksi yang dilakukan dengan Jaringan Syaraf Tiruan tidak berbeda jauh dari data aktual PT. PDAM Kota Duri. Hasil akhir dari penelitian ini adalah Jaringan syaraf tiruan menggunakan metode backpropagation dapat memprediksi penggunaan konsumsi air di PT. PDAM Kota Duri untuk tahun selanjutnya.

Maka dapat disimpulkan bahwa model terbaik adalah pola 8-9-1 dengan proses epoch pelatihan $=4595$ dan pencapaian MSE pada saat pengujian dengan MSE = 0,001 dengan akurasi 99,99900000\% (100-MSE).

\section{Kesimpulan}

\subsection{Simpulan}

Berdasarkan analisa data pada pelatihan (training) dan pengujian (testing) tentang prediksi penggunaan air di PT. PDAM Kota Duri, maka dari penelitian ini dapat diambil beberapa kesimpulan sebagai berikut :

1. Penerapan metode Jaringan Syaraf Tiruan (JST) dengan algoritma backpropagation dapat memprediksi jumlah volume penggunaan air di masa mendatang pada PT. PDAM Kota Duri dengan menggunakan Matlab R2011b. Dengan menerapkan arsitektur jaringan yang paling tepat untuk digunakan dalam memprediksi penggunaan konsumsi air adalah dengan pola arsitektur 8-9-1 dengan hasil persentasi 99,99900000\%

2. Penentuan dan pendataan variabel dapat diterapkan pada metode Jaringan Syaraf Tiruan (JST) dan dapat membantu mengatasi jumlah produksi air di PT. PDAM Kota Duri.

\subsection{Saran}

Berdasarkan hasil penelitian yang telah penulis lakukan melalui proses pelatihan data dan pengujian data dengan algoritma backpropagation, saran yang dapat diberikan adalah sebagai berikut.

1.Perlu dilakukan proses prapengolahan (preprocessing) yang lebih kompleks dengan data yang lebih banyak karena jumlah data mempengaruhi tingkat akurasi data.

2. Jumlah lapisan tersembunyi (hidden layer) yang digunakan ditambah lebih banyak untuk meneliti keakuratan jaringan dalam memprediksi penggunaan konsumsi air di PT. PDAM Kota Duri .

3. Diharapkan adanya pengembangan lebih lanjut agar dapat lebih meningkatkan pemahaman terhadap algoritma backpropagation dalam melakukan prediksi.Berisi saran-saran perbaikan dan penelitian lanjutan. 


\section{Daftar Rujukan}

[1] Monica, Mesran, Suginam, \& Karim. (2017). Jambu Biji Menggunakan Metode Bayes, 2(1), 78-81.

[2] Kung, J., Kim, D., \& Mukhopadhyay, S. (2015). A poweraware digital feedforward neural network platform with backpropagation driven approximate synapses. Proceedings of the International Symposium on Low Power Electronics and Design, 2015-Septe, 85-90. https://doi.org/10.1109/ISLPED.2015.7273495

[3] Pan, X., Lee, B., \& Zhang, C. (2013). A comparison of neura network backpropagation algorithms for electricity load forecasting. In Proceedings - 2013 IEEE International Workshop on Intelligent Energy Systems, IWIES 2013 (pp. 22-27). https://doi.org/10.1109/IWIES.2013.6698556

[4] Huang, D., \& Wu, Z. (2017).

Forecasting outpatient visits using empirical mode decomposition coupled with backpropagation artificial neural networks optimized by particle swarm optimization. PLoS ONE, 12(2). https://doi.org/10.1371/journal.pone.0172539

[5] Hrasko, R., Pacheco, A. G. C., \& Krohling, R. A. (2015). Time Series Prediction Using Restricted Boltzmann Machines and Backpropagation. Procedia Computer Science, 55, 990 999. https://doi.org/10.1016/j.procs.2015.07.104

[6] Lahmiri, S. (2014). Wavelet low- and high-frequency components as features for predicting stock prices with backpropagation neural networks. Journal of King Saud University - Computer and Information Sciences, 26(2), 218227. https://doi.org/10.1016/j.jksuci.2013.12.001
[7] Nugraha, A. P. (2015). Aplikasi Sistem Pakar Untuk Mendiagnosa Penyakit Dalam Menggunakan Metode Forward Chaining Dan Certainty Factor Berbasis Web ( Studi Kasus : Poliklinik Pt Pos Indonesia Bandung ) Application of Expert System to Diagnose Internal Disease Using Forward Chai, 2(2), 3676-3683.

[8] Rahayu, S. (2013). Sistem pakar untuk mendiagnosa penyakit gagal ginjal dengan menggunakan metode bayes. Pelita Informatika Budi Darma, IV(3), 129-134

[9] Ihwan, A. (2013). Metode Jaringan Saraf Tiruan Propagasi Balik Untuk Estimasi Curah Hujan Bulanan di Ketapang Kalimantan Barat, 243-247.

[10] Zekson Arizona Matondang, (2013). "Jaringan Syaraf Tiruan dengan Algoritma Backpropagation untuk Penentuan Kelulusan Sidang Skripsi”. Pelita Informatika Budi Darma, 1 Agustus

[11] Abidah, S. (2013). Analisis komparasi metode tsukamoto dan sugeno dalam prediksi jumlah siswa baru. Jurnal Teknologi Informasi Dan Komunikasi, 8(2), 57-63.

[12] Simangunsong, F. R. D. B., \& Nasution, S. D. (2015). Aplikasi Jaringan Saraf Tiruan Untuk Memprediksi Metode Back Propagation, 2(6), 43-47.

[13] Ujianto, Y., dan Isa, M. (2015). Perbandingan Performansi Metode Peramalan Fuzzy Time Series yang Dimodifikasi dan Jaringan Syaraf Tiruan Backpropagation (Studi Kasus: Penutupan Harga IHSG), 4(2).

[14] Dar, M. H. (2017). Penerapan Metode Backpropagation Neural Network Untuk Memprediksi Produksi Air, 12, 203208 